\title{
Food niche overlap among neotropical frugivorous bats in Costa Rica
}

\author{
Jorge E. Lopez ${ }^{1} \&$ Christopher Vaughan ${ }^{2}$ \\ 1 International Institute for Wildlife Conservation and Management (ICOMVIS), Universidad Nacional, Apartado 1350, \\ Heredia, Costa Rica. Current address: Universidad de San Carlos, Guatemala, Guatemala; jelopez@usac.edu.gt \\ 2 International Institute for Wildlife Conservation and Management, Universidad Nacional, Apartado 1359, Heredia, \\ Costa Rica. Current address: ICOMVIS, Department of Wildlife Ecology, University of Wisconsin, Madison, WI \\ 53706 and Milwaukee Public Museum, Milwaukee, WI 53233-1478; cvaughan@wisc.edu
}

\author{
Received 17-V-2003. Corrected 10-I-2006. Accepted 13-XI-2006.
}

\begin{abstract}
Food habits of 15 species of frugivorous bats were studied at La Selva Biological Station, Costa Rica. Eight hundred and fifty-four (854) fecal samples and 169 samples from fruit parts and seeds discarded by bats beneath feeding roosts were analyzed. During eight months of study, 47 fruit species consumed by bats were identified. Five plant genera (Cecropia, Ficus, Piper, Solanum, and Vismia) constituted 85\% of all plants found in fecal samples. Feeding niche breadth differed significantly among the six most common species of frugivorous bats (Artibeus jamaicensis, Carollia sowelli, C. castanea, C. perspicillata, Dermanura sp., and Glossophaga commissarisi). All species, except for Dermanura sp., showed a diet dominated by one or two plant species. This suggests a pattern of resource partitioning at a generic level, in which Carollia consumed mainly Piper, Artibeus consumed Ficus and Cecropia, and Glossophaga consumed Vismia. Cluster analysis revealed higher values of food niche overlap in congeneric species than among species of different genera. Results show that if food is a limiting factor, mechanisms other than trophic selection must reduce interspecific interference or competition for food in this frugivorous bat guild. Rev. Biol. Trop. 55 (1): 301-313. Epub 2007 March. 31.
\end{abstract}

Key words: Costa Rica, food habits, frugivorous bats, guilds, La Selva Biological Station, trophic structure.

In tropical environments, nearly $80 \%$ of plants produce fruits dispersed by vertebrates (Frankie et al. 1974, Janzen 1978, Opler et al. 1980, Charles-Dominique 1991, Ganesh and Davidar 2001). In some tropical areas, over $90 \%$ of pioneer plants produce fruits eaten by bats and birds (Charles-Dominique 1986). Plants dispersed by bats produce green fruits externally located on the plant upon maturing to favor their removal by flying animals (Charles-Dominique 1991). Bats are considered instrumental in regeneration of forests on abandoned mining areas (Parrotta et al. 1997), islands (Shanahan et al. 2001), and agricultural areas (Galindo 1998, Medellin and Gaona 1999, Galindo et al. 2000). Bats are also affected by extensive alteration of forest environments (Ochoa 2000, Schulze et al. 2000, Pacheco et al. 2006).

Of neotropical vertebrates, bats as a group have the greatest number of frugivorous species (Fleming et al. 1987, Levey et al. 1994). Bats also have a tendency to disperse seeds towards open areas normally visited less frequently by other dispersal agents (Stashko and Kunz 1987). In Central America, many plant species, such as Ficus, Cecropia, Piper and Muntingia, are dispersed by frugivorous bats (Morrison 1978, Bonaccorso 1979, Fleming 1981, Fleming and Heithaus 1981, Fleming 1982, Fleming et al. 1985, Charles-Dominique 1986, Fleming 1988). Fleming (1986a) found that the abundance of frugivorous bats in two tropical forests in Costa Rica was twice that of 
insectivorous and nectarivorous bats. Frugivory plays an important role in determining bat community structure in the tropics (Heithaus et al. 1975). Competition for food resources is thought to be a key element in bat community structure (McNab 1971, Fleming et al. 1972, Sosa and Soriano 1993, Muñoz-Romo et al. 2005). Fleming (1986a) proposed that mutualistic relations between bats and plants are very important in determining structure of bat communities. However, empirical data are needed to support or refute ideas proposed by the above-mentioned authors. The objective of this study is to evaluate trophic assemblages of frugivorous bats by studying their food habits at La Selva Biological Station, Costa Rica (LSBS).

\section{MATERIALS AND METHODS}

Study area: LSBS is administered by the Organization for Tropical Studies (OTS) and is located approximately $2 \mathrm{~km}$ east of the town of Puerto Viejo de Sarapiqui, Heredia Province, Costa Rica $\left(10^{\circ} 26^{\prime} \mathrm{N}, 83^{\circ} 59^{\prime} \mathrm{W}\right)$. LSBS, is 1536 ha in size and located at the base of the Central Volcanic Mountain Range with an elevation varying between 35 and 137 m.a.s.l. (McDade and Hartshorn 1994). LSBS contains a mosaic of forest types in successional states within the tropical humid forest and premontane rain forest life zones (Hartshorn and Hammel 1994). Annual precipitation is $3962 \mathrm{~mm}$ with the greatest amount (over 400 $\mathrm{mm} / \mathrm{mo}$ ) falling between June and July and November and December while the least falls between February and April. Average monthly temperature is $25.8{ }^{\circ} \mathrm{C}$ with little monthly variation (Sanford et al. 1994).

Sample sites: using aerial photographs, topographic maps and field visits, four sites were selected which provided the greatest variability in secondary forest types. The vegetation types were: a) early successional pastures, b) young secondary forest, c) abandoned plantations, and d) mature secondary forest (Hartshorn and Hammel 1994).

Captures: Between January and August 1995, each site was sampled on a monthly basis for bat species and numbers. Each sampling event consisted of four consecutive capture nights between 17:30 and 24:00 hours using four to six mistnets, each measuring $18.6 \times 2.7$ $\mathrm{m}$ and with a $4 \mathrm{~cm}^{2}$ mesh (Avinet Inc., Dryden, New York 13053-1103). Each bat specimen captured was identified, measured, weighed, sexed, and reproductive condition and age class were determined. Age class was determined for each bat by considering fur condition and color, corporal mass and level of fusion between metacarpal epiphyses.

Food habits: diet was studied by collecting feces from mistnetted individuals and feces and fruit parts found under resting bat tents and feeding perches (Thomas 1988). Individuals captured in mistnets were placed in a clean cloth bag for up to two hours to obtain fecal samples and then liberated. Each fecal sample was stored in an individual waxed paper envelope and the following information was taken: identity number, species, capture site and date. Also, piles of pulp and seed parts regurgitated during bat feeding (Handley et al. 1991) were found at resting or sleeping perches in hollow trees, underneath foliage and in leaf-tents used by bats of tribe Stenodermatini y (Timm 1987). To collect fruit and seed samples, a plastic screen supported by four stakes (so it did not touch the ground) was placed in the afternoon under each perch and checked the following morning. All fruit and seed samples were placed in waxed paper envelopes, and the following data were taken: date, perch location, perch type and bat species (when possible). Samples were left drying at room temperature inside the envelopes.

Reference collection of fruits and seeds: during the study period, a reference collection was made of fruits and seeds found in 
the sampled forest types. Monthly collections of fruiting plants potentially eaten by bats were placed in the herbarium at LSBS. Fruit and seed samples preserved in $70 \%$ ethanol formed the reference fruit and seed collection. Plant species were identified by botanists and a reference collection deposited in the herbarium at the Instituto Nacional de Biodiversidad (INBio). A stereoscope was used to compare fruit and seed parts found in bat feces to reference collections. In difficult cases, taxonomists identified plant species. Insects were included in the analysis. Presence or absence of insects and plant species was noted for each sample. A sample was defined as presence of one or more seeds of a determined plant or insect parts in each fecal sample.

Data analysis: The program NICHE (Krebs 1989) was used to calculate food niche breadth and overlap indices. To estimate food niche breadth, Levin's standardized measurement was used (Colwell and Futuyma 1971). Pianka's (1973) symmetric equation was used to estimate food niche overlap index. This index varies between 0 (no overlap) to 1 (total overlap). Indices were recalculated using the jackknife method that estimated $95 \%$ confidence intervals (Sokal and Rohlf 1981, Krebs 1989). The jackknife index of food niche breadth was compared for the six most frequently captured bat species, with a Kruskal-Wallis test (Sokal and Rohlf 1981). A KolmogorovSmirnov test (Sokal and Rohlf 1981) was used to determine if differential consumption existed between principal plant genera in a bat species diet. For the tests, the statistical package STATGRAPHICS PLUS was used (Statistical Graphics Corporation 1994). Using feeding niche overlap indices, a trophic overlap matrix was made. Based on this matrix, a cluster analysis was performed (Jaksic and Medel 1987). The results of this analysis were graphed as a phenogram of trophic niche overlap comparing the nine most commonly captured frugivorous bat species. For cluster analysis, non-weighted arithmetic means employing SYSTAT for Windows were used (Systat Incorporate 1992).

\section{RESULTS}

Captures: during eight months between January and August 1995, 1426 bats were captured at the four sample sites. Of total captures, 1316 individuals (92\%) were of 15 frugivorous bat species. At each sample site, monthly sampling effort was 144 net hours $(\mathrm{SD}=15.3$ net hours) for a total effort of 1152 net hours with bat captures. An average 1.14 bats were captured per net hour.

Food habits: the captured 15 species of frugivorous bats produced 854 fecal samples $(64.8 \%)$. One hundred and sixty-nine (169) fecal samples and food parts were found under perches (Table 1). About $92 \%$ of fecal samples came from the six bat species (Artibeus jamaicensis, Carollia sowelli, C. castanea, C. perspicillata, Dermanura sp. and Glossophaga commissarisi) captured most frequently at LSBS. Fecal samples from the remaining nine bat species were rare or infrequent (Table 1).

During the study, fruit or seeds of 47 identified plant species were consumed by one or more of the 15 frugivorous bat species in LSBS. Forty-two plant species were identified in bat feces (Table 2) and five additional plant species were found in feces or fruits ejected under tents and feeding stations (Dipteryx panamensis, Hernandia stenura, Quararibea parvifolia, Symphonia globulifera and Spondias radlkoferi). Seeds of four shrub species (Piper sancti-felicis, P. auritum, P. multiplinervium, Vismia panamensis) and a cecropia (Cecropia obtusifolia) made up over $50 \%$ of the samples (Table 2). The genus Piper was most commonly found (55\%), while Vismia was a distant second (8.5\%).

Fruit and seed species richness consumed by frugivorous bats was greater during the dry season than the wet season (Table 3). However the proportion of samples declined during the dry season. Total numbers of samples of the most common plant genera in the feces (Ficus, Piper, Solanum, and Vismia) for the six most commonly captured bat species were significantly different (Kolmogorov-Smirnov D = $1.73, \mathrm{p}=0.0049)$. 
TABLE 1

Monthly frequency of frugivorous bat feces collected at La Selva Biological Station, Heredia, Costa Rica (January-August 1995)

\begin{tabular}{lccccccccc}
\multicolumn{1}{c}{ Species } & January & February & March & April & May & June & July & August & Total \\
Artibeus jamaicensis & 5 & 15 & 9 & 8 & 10 & 36 & 1 & 4 & 88 \\
A. lituratus & 1 & 5 & 0 & 0 & 4 & 0 & 1 & 0 & 11 \\
Carollia sowelli & 21 & 21 & 31 & 37 & 32 & 26 & 39 & 0 & 207 \\
C. castanea & 57 & 15 & 11 & 30 & 19 & 30 & 39 & 2 & 203 \\
C. perspicillata & 38 & 20 & 12 & 20 & 22 & 7 & 16 & 0 & 135 \\
C. sp. & 4 & 0 & 0 & 0 & 0 & 0 & 0 & 0 & 4 \\
Chiroderma villosum & 0 & 0 & 0 & 0 & 0 & 10 & 0 & 0 & 10 \\
Dermanura spp. & 2 & 2 & 16 & 9 & 9 & 10 & 20 & 2 & 70 \\
Glossophaga commissarisi & 0 & 0 & 0 & 9 & 45 & 17 & 11 & 0 & 82 \\
Hylonycteris underwoodi & 0 & 0 & 0 & 1 & 1 & 3 & 0 & 0 & 5 \\
Phylloderma stenops & 0 & 1 & 0 & 0 & 1 & 0 & 0 & 0 & 2 \\
Sturnia lilium & 0 & 0 & 1 & 1 & 0 & 0 & 0 & 1 & 3 \\
Uroderma bilobatum & 0 & 0 & 3 & 0 & 0 & 3 & 1 & 0 & 7 \\
Vampyressa nymphaea & 2 & 3 & 1 & 1 & 1 & 2 & 0 & 0 & 10 \\
V. pusilla & 2 & 0 & 0 & 0 & 0 & 1 & 1 & 0 & 4 \\
Vampyrops helleri & 1 & 1 & 2 & 2 & 2 & 6 & 1 & 0 & 13 \\
Totals & 132 & 82 & 84 & 116 & 144 & 145 & 129 & 9 & 854
\end{tabular}

Trophic niche breadth indices (jackknife estimates) for the six most abundant bat species (Table 4) were significantly different (KruskalWallis $\mathrm{H}=93.06, \mathrm{p}<0.001)$. Bat species with the greatest feeding niche overlap were Vampyressa nymphaea and Vampyrops helleri, followed by Carollia perspicillata and $C$. sowelli (Table 5). Using cluster analysis, two groups were differentiated (Fig. 1): a) species from the genus Carollia and Glossophaga and b) species from the tribe Stenodrematini ( $A$. jamaicensis, A. lituratus, Dermanura sp., $V$. helleri, and $V$. nymphaea).

April and May were the months of greatest reproductive activity for lactating or pregnant females. These events were associated with an increase in consumption of two food items (Fig. 2). A significant positive correlation was found between the number of female reproductive events and number of insects consumed
$\left(\mathrm{R}^{2}=0.821, \mathrm{p}<0.05\right)$ and Vismia panamensis, an understory shrub $\left(\mathrm{R}^{2}=0.892, \mathrm{p}<0.05\right)$. Other food items showed no significant relationship between reproductive events and consumption rate.

\section{DISCUSSION}

Bat food niches: at least 18 frugivorous bat species coexist at LSBS. This is $28 \%$ of LSBS's reported bat species (Howell and Burch 1974, Gardner 1977, Levey et al. 1994, Timm 1994). McNab (1971) stated that two sympatric species coexist in equilibrium only if sufficient differences exist between their ecological niches. Food is a parameter in the bat ecological niche that can be used to test McNab's (1971) hypothesis (Fleming et al.1972). In this study, frugivorous bat seed 
TABLE 2

Fruit seed occurrence in frugivorous bat feces. The quantities represent the number of fecal samples which contain a determined item. La Selva Biological Station, Costa Rica (January-August, 1995)

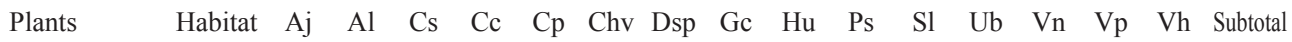
VINES\& SHRUBS

\begin{tabular}{|c|c|c|c|c|c|c|c|c|c|c|c|c|c|c|c|c|}
\hline Anthurium sp. & $\mathrm{M}$ & & & 3 & & & & & & & & & & & & 3 \\
\hline Passiflora $\mathrm{sp}$. & $\mathrm{S}$ & & & & & 1 & & & & & 1 & & & & & 2 \\
\hline Philodendron sp. & $\mathrm{M}$ & & & 14 & 2 & 3 & & 1 & 1 & & & & & & & 21 \\
\hline Markea neuratha & $\mathrm{M}$ & & & 5 & & 2 & & 1 & 5 & 3 & & & & & & 16 \\
\hline Ficus cahuitensis & $\mathrm{S}$ & 32 & 2 & & & & 8 & 1 & & & & 1 & 3 & & 3 & 50 \\
\hline F. nymphaeifolia & $\mathrm{M}$ & 4 & 1 & & & & & & & & & & & & & 5 \\
\hline F. pertusa & $\mathrm{S}$ & & & & & & & 1 & & & & & & & & 1 \\
\hline \multicolumn{17}{|l|}{ SHRUBS } \\
\hline Piper aduncum & $\mathrm{S}$ & & & 2 & 2 & 1 & & & & & & & & & & 5 \\
\hline P. augustum & $\mathrm{S}$ & & & 5 & 1 & 1 & & & & & & & & & & 7 \\
\hline P. auritum & $\mathrm{S}$ & 1 & 1 & 58 & 2 & 29 & & 19 & 14 & & & & & & & 126 \\
\hline P. colonense & $\mathrm{S}$ & & & 13 & 12 & 2 & & 6 & 1 & & & & & & & 34 \\
\hline P. friedrichsthalii & $\mathrm{S}$ & & & 2 & 17 & 9 & & & 1 & & & & & & & 29 \\
\hline P. glabratum & $\mathrm{S}$ & & & 7 & 29 & 6 & & 5 & 2 & & & & & & & 49 \\
\hline P. hispidum & $\mathrm{S}$ & & & & & 1 & & & & & & & & & & 1 \\
\hline P. multiplinervium & $\mathrm{S}$ & & & 21 & 64 & 33 & & 1 & & & & & & & & 119 \\
\hline P. reticulatum & $\mathrm{S}$ & & & & 3 & 3 & & & & & & & & & & 6 \\
\hline P. sancti-felicis & $\mathrm{S}$ & 1 & & 43 & 69 & 17 & & 14 & 2 & & & 1 & 1 & & & 148 \\
\hline P. trigonum & $\mathrm{M}$ & & & 5 & 9 & & & & & & & & & & & 14 \\
\hline P. sp. 1 & & & & & 4 & & & & & & & & & & & 4 \\
\hline P. sp. 2 & & & & 1 & & & & & & & & & & & & 1 \\
\hline P. "umbrella" & & & & & 1 & & & & & & & & & & & 1 \\
\hline P. "aborted" & & & & 3 & 3 & & & & & & & & & & & 6 \\
\hline$P$. "bell" & & & & 2 & 5 & 1 & & & & & & & & & & 8 \\
\hline Pothomorphe peltata & $\mathrm{S}$ & & & 1 & 1 & & & & & & & & & & & 2 \\
\hline Senna fructicosa & $\mathrm{S}$ & & & 1 & 1 & 5 & & & & & & & & & & 7 \\
\hline Solanum arboreum & $\mathrm{S}$ & & & 2 & 2 & 2 & & & & & & & & & & 6 \\
\hline S. rugosum & $\mathrm{S}$ & 1 & & 19 & 7 & 15 & & 1 & 1 & & & 3 & 4 & & & 51 \\
\hline Vismia panamensis & $\mathrm{S}$ & 5 & 4 & 25 & 4 & 21 & & 2 & 25 & 1 & & & & & & 87 \\
\hline \multicolumn{17}{|l|}{ TREES } \\
\hline Annona sp. & M & & & & & & & & & & 2 & & & & & 2 \\
\hline Cecropia insignis & A & & & & & & & & 8 & & & & & & & 8 \\
\hline C. obtusifolia & A & 23 & 4 & & & & 1 & 16 & 1 & & & 1 & 5 & 1 & 10 & 62 \\
\hline Clarisia mexicana & $\mathrm{A}$ & 1 & & & & & & & & & & & & & & 1 \\
\hline
\end{tabular}


TABLE 2 (Continued)

Fruit seed occurrence in frugivorous bat feces. The quantities represent the number of fecal samples which contain a determined item. La Selva Biological Station, Costa Rica (January-August, 1995)

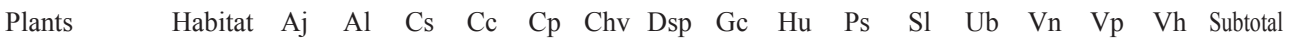

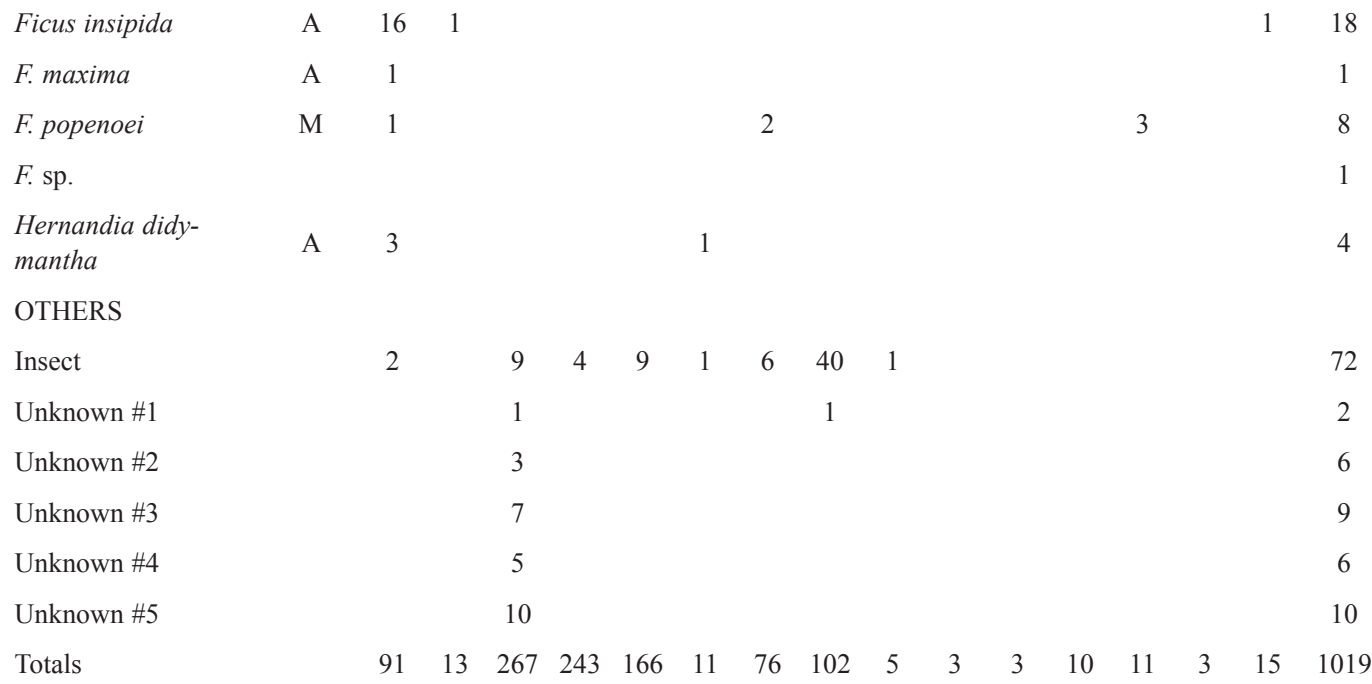

Key for abbreviations: $\mathrm{Aj}=$ Artibeus jamaicensis, $\mathrm{Al}=$ Artibeus lituratus, $\mathrm{Cs}=$ Carollia sowelli, $\mathrm{Cc}=\mathrm{Carollia}$ castanea, $\mathrm{Cp}=$ Carollia perspicillata, $\mathrm{Chv}=$ Chiroderma villosum, Dspp $=$ Dermanura spp., Gc $=$ Glossophaga commissarisi, $\mathrm{Hu}=$ Hylonycteris underwoodi, Ps = Phylloderma stenops, $\mathrm{Sl}=$ Sturnira lillium, Ub = Uroderma bilobatum, Vn $=$ Vampyressa nymphaea, $\mathrm{Vp}=$ Vampyressa pusilla, $\mathrm{Vh}=$ Vampyrops helleri, $\mathrm{M}, \mathrm{A}$ and $\mathrm{S}$ ??

TABLE 3

Seasonal diversity of fruit consumed by bats. La Selva Biological Station, Heredia, Costa Rica (January-August 1995)

$\begin{array}{lcccc}\text { Species } & \begin{array}{c}\text { Number of } \\ \text { fruit species }\end{array} & \begin{array}{c}\text { Number of } \\ \text { fruit species }\end{array} & \begin{array}{c}\text { Proportion fruit } \\ \text { samples/capture }\end{array} & \begin{array}{c}\text { Proportion fruit } \\ \text { samples/capture }\end{array} \\ \text { (January-April) } & \begin{array}{c}\text { Wet season } \\ \text { (May-August) }\end{array} & \begin{array}{c}\text { Dry season } \\ \text { (January- April) }\end{array} & \begin{array}{c}\text { Wet season } \\ \text { (May-August) }\end{array} \\ \text { sowelli } & 17 & 12 & 0.80 & 0.75 \\ \text { castanea } & 18 & 16 & 0.82 & 0.85 \\ \text { s jamaicensis } & 14 & 12 & 0.78 & 0.90 \\ \text { mura } \text { sp. } & 9 & 7 & 0.85 & 0.90\end{array}$


TABLE 4

Trophic niche breath (B) for six frugivorous bat species. La Selva Biological Station, Heredia Province, Costa Rica ( January-August 1995)

\begin{tabular}{lcccc}
\hline \multicolumn{1}{c}{ Specie } & B & B-jackknifed & SD & $95 \%$ CI \\
\hline Dermanura sp. & 0.389 & 0.387 & 0.02441 & $0.3730-0.4012$ \\
Carollia perspicillata & 0.369 & 0.356 & 0.01534 & $0.3488-0.3623$ \\
Carollia sowelli & 0.344 & 0.347 & 0.01784 & $0.3396-0.3541$ \\
Artibeus jamaicensis & 0.286 & 0.284 & 0.02826 & $0.2667-0.3009$ \\
Glossophaga commissarisi & 0.254 & 0.253 & 0.02894 & $0.2358-0.2708$ \\
Carollia castanea & 0.204 & 0.204 & 0.011013 & $0.1996-0.2082$
\end{tabular}

TABLE 5

Trophic overlap matrix between nine frugivorous bat species according to the Pianka sympatric index (Krebs 1989). La Selva Biological Station, Heredia Province, Costa Rica. (January-August 1995)

\begin{tabular}{|c|c|c|c|c|c|c|c|c|c|}
\hline & $\mathrm{Aj}$ & $\mathrm{Al}$ & Cs & $\mathrm{Cc}$ & $\mathrm{Cp}$ & Dspp & Gc & $\mathrm{Vh}$ & $\mathrm{Vn}$ \\
\hline $\mathrm{Aj}$ & ---- & 0.725 & 0.071 & 0.024 & 0.085 & 0.353 & 0.116 & 0.748 & 0.816 \\
\hline $\mathrm{Al}$ & & & 0.295 & 0.028 & 0.321 & 0.489 & 0.374 & 0.714 & 0.721 \\
\hline Cs & & & & 0.595 & 0.863 & 0.076 & 0.452 & 0.000 & 0.196 \\
\hline $\mathrm{Cc}$ & & & & & 0.689 & 0.428 & 0.101 & 0.000 & 0.116 \\
\hline $\mathrm{Cp}$ & & & & & & 0.577 & 0.488 & 0.000 & 0.136 \\
\hline Dspp & & & & & & & 0.407 & 0.514 & 0.635 \\
\hline Gc & & & & & & & & 0.019 & 0.069 \\
\hline $\mathrm{Vh}$ & & & & & & & & & 0.933 \\
\hline $\mathrm{Vn}$ & & & & & & & & & \\
\hline
\end{tabular}

Key for abbreviations: $\mathrm{Aj}=$ Artibeus jamaicensis, $\mathrm{Al}=$ Artibeus lituratus, $\mathrm{Cb}=$ Carollia sowelli, $\mathrm{Cc}=\mathrm{Carollia}$ castanea, $\mathrm{Cp}=$ Carollia perspicillata, Dspp $=$ Dermanura spp., $\mathrm{Gc}=$ Glossophaga commissarisi, $\mathrm{Vn}=$ Vampyressa nymphae, $\mathrm{Vh}=$ Vampyrops helleri.

and fruit consumption patterns for 47 fruit species differed among bat species. Food habit indices differed significantly among the most common frugivorous bat species at LSBS and significant differences were found in fruit consumption patterns between bats at the generic level (Table 2).

Frugivorous bats in LSBS most frequently consumed common plant taxon (genus or species) and supplemented their diet with lessfrequently consumed species. Seeds from the genus Piper appeared six times more frequently in feces than Vismia, the next most common plant genus. Only four of the 15 bat species studied did not consume Piper fruits, indicating its importance in frugivorous bat diets in LSBS.

According to Fleming (1988), bats favor seeds and fruits from plant species fruiting year-round, because they offer a predictable food source. Bats complement this diet with other less stable food types, which vary spatially and temporally. In LSBS, Artibeus consumed principally Ficus and Cecropia, Carollia consumed Piper, and G. commissarisi consumed Vismia. These plant genera in LSBS produce fruit all year (Hammel 1986a, Hammel 1986b, Greig 1993a, Greig 1993b). We conclude that 


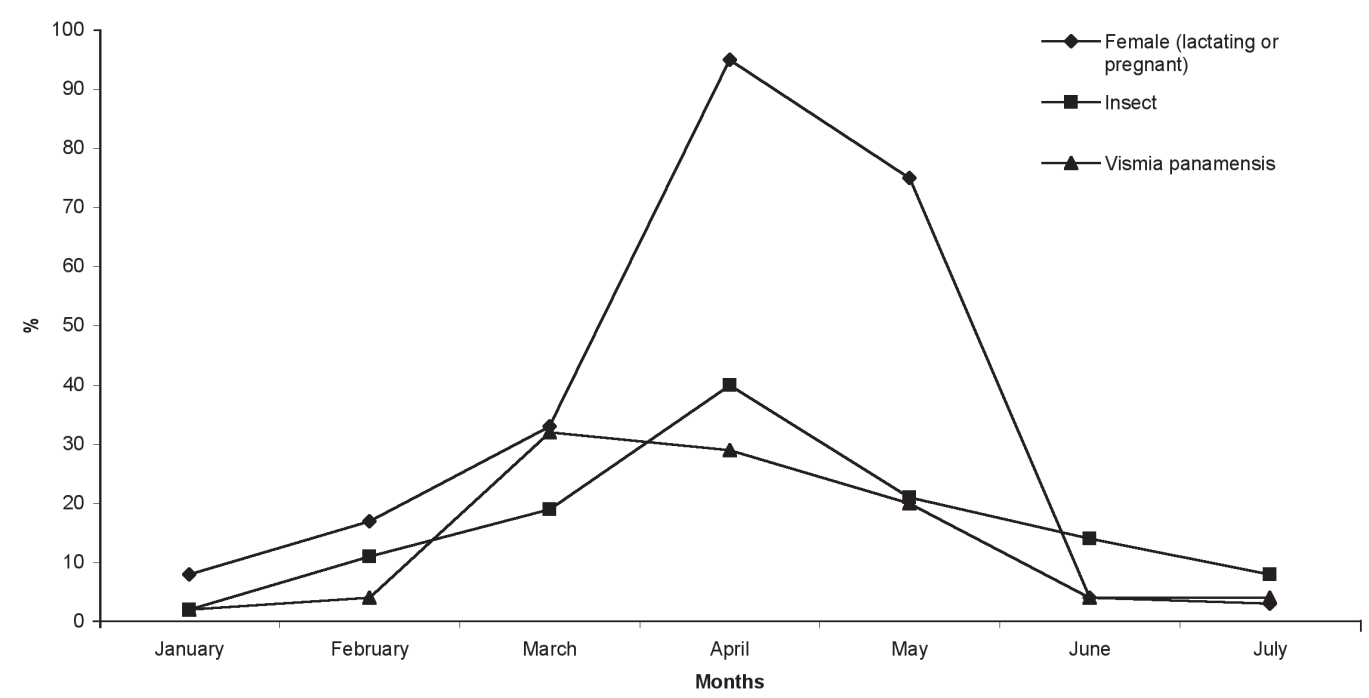

Fig. 1. Comparison between monthly percent of captured female bats lactating or pregnant and monthly percentage of insect or Vismia panamensis fruits found in bat feces.

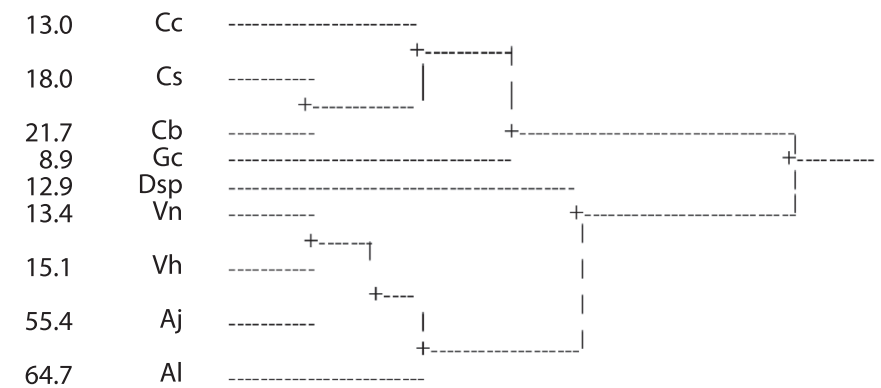

Similarity (Piankas symmetry index)

Abbreviations:

$\mathrm{CC}=$ Carollia castanea $\quad \mathrm{Vn}=$ Vampyressa nymphaea

$\mathrm{Cs}=\mathrm{C}$. perspicillata $\quad \mathrm{Vh}=$ Vamphyrops helleri

$\mathrm{Cb}=\mathrm{C}$. sowelli $\quad \mathrm{Aj}=$ Artibeus jamaicensis

$\mathrm{Gc}=$ Glossophaga commisarisi $\quad \mathrm{Al}=\mathrm{A}$. lituratus

Dsp $=$ Dermatura spp.

Fig. 2. Phenogram of trophic niche overlap between frugivorous bats, based on the Pianka index (Krebs 1989).

in LSBS, Artibeus, Carollia, and Glossophaga behave as proposed by Fleming (1988).

Food niche overlap: the six most abundant frugivorous bat species in LSBS showed greatest niche overlap between congeners; the same observed with the three least abundant species. This contradicts Hutchinson (1959) who noted that sympatric congeners usually differ in their diets. However, our study (and others) found that congeneric bat species have similar diets (Tamsitt, 1967, Fleming et al. 1972, Marinho-Filho 1991). Therefore, high trophic niche overlap values between congeneric species suggests that the potential exists for competition or that species coexist in apparent equilibrium and other niche dimensions are involved in resource partitioning. Gorchov et al. (1995) found little overlap in diet between 31 and 29 species of frugivorous bats and birds, while Muller and Reis (1993) found partitioning of food resources among the most common bat species they studied.

Cluster analysis: two groups of frugivorous bat food habits in LSBS were revealed (Fig. 1). The first is composed of four species, three from the genus Carollia and G. commissarisi. The second consists of five species from the subfamily Stenoderminae. These groups 
coincide with functional understory and canopy bat frugivore guilds described by Bonaccorso (1979) for Barro Colorado Island, Panama. However, more trophic similarity exists between species with similar weights. Perhaps differences in the size of food items consumed by bats could explain differences in bat diets when similar weights and plants are consumed (Bonaccorso 1979). Among the Stenoderminae, Dermanura sp. had a more diverse diet and one less dominated by members of the genus Ficus. Dermanura sp., together with G. commissarissi, constituted a group of understory generalists.

Seasonality of fruiting patterns: a possible factor explaining seasonality of fruiting patterns in tropical forests is seed disperser competition (Snow 1965). This study partially confirms the hypothesis that seed dispersers have seasonal food habits. Bat diet in LSBS was more diverse in the dry season (JanuaryApril) then wet season (May-August). Also, there were fewer items/feces found during the dry season because it is the season of least fruit abundance in LSBS (Opler et al. 1980, Newstrom et al. 1994). This coincides with optimal foraging strategy predictions (Pyke et al 1977, Anderson 1983).

Bat reproductive cycles: an important consequence of phenological seasonality is found in bat reproductive cycles (Racey 1988). Kunz (1980) found pregnancy and lactation were more energetic expensive for female bats. During lactation in rodents, females increase energetic demands between 66-133\% (Randolph et al. 1977, Millar 1978). Although Dinerstein (1981) came to different conclusions working in cloud forest environments, insects as a food item were associated with frugivorous bats' reproductive events in LSBS. Correlations observed between female bat reproductive events and insect (high energy and protein sources) and $V$. panamensis consumption suggests that both can be critical resources for frugivorous bats during reproduction in LSBS, particularly during lactation (Bonaccorso 1979, Autino and Barquez 1993). We feel that this important discovery with frugivorous bats has been underemphasized in the literature.

Potential sources of error: lack of collecting data for at least a year could contribute to underestimating the value of some food sources for certain bat species and not finding "keystone" food resources such as fig (Korine et al. 2000). Also subestimating or not accounting for undigested fruits because seeds were undetected was a possible source of error. Four species of seeds found under feeding stations and tents were not detected in fecal samples. However, large-seeded species $(>5 \mathrm{~mm})$ were more frequently represented under tents and feeding stations than from feces because they were ejected and not swallowed. Perhaps bats use feeding perches to manipulate large fruits or those requiring more time to be ingested (Thomas 1988). Another source of error is differential defecation rate of bat species. For example, $80 \%$ of captured $C$. castanea individuals yielded feces, compared to only $42 \%$ of $A$. jamaicensis individuals. A similar tendency is seen with the other carolliine species (C. sowelli, C. perspicillata) and Stenodermatini (A. lituratus, Dermanura sp., Chiroderma villosum, $V$. nymphaea, $V$. helleri). Perhaps these individual bat species manipulate fruit differently. Fleming (1986b) found that Carollia species consume fruits in two minutes or less, ingesting most seeds. However, A. jamaicensis take over ten minutes to process a fruit and ingests few seeds. This partially explains differences in fecal sample size when similar numbers of a species were captured and has implications for bat seed dispersal efficacy. A fourth source of error may be related to differences in nutritional values of food sources (Wendeln et al. 2000), which could greatly influence food preferences, reproduction and other variables. A final source of error was not accounting for vertical stratification of bat communities (Bernard 2001, Kalko and Handley 2001) as we only sampled the lower strata.

Conservation of bats, rain forests and regeneration: conserving and managing plants 
used as food by frugivorous bats is important to maintain populations of frugivorous bats and ensure plant species dispersal. This study found that bats consume many pioneer plant species and thus, some bat species could be favored by increases in secondary forest areas. However, bats also depend on primary forest areas that provide needed resources, such as refuge, feeding sites and food. As Kalko and Handley (2001) and Cosson et al. (1999) have discussed, habitat alteration affects understory fruit bat species more than canopy species. Brosset et al. (1996) found that over $60 \%$ of bat species found in forested habitats were absent from deforested areas in French Guiana. Both habitats are necessary for bat conservation. And regeneration of tropical forests is likewise dependent on dispersers such as bats.

\section{ACKNOWLEDGEMENTS}

We thank the personal at LSBS for their assistance, the Universidad Nacional, the German Academic Exchange Program(DAAD), Idea Wild and the United States Department of Agriculture (Cooperative Agreement 127522000-189-04S with the Milwaukee Public Museum). This publication is part of the "Theobroma cacao: Biodiversity in full and partial canopies" research project, coordinated by the Milwaukee Public Museum.

\section{RESUMEN}

Estudiamos los hábitos alimentarios de 15 especies de murciélagos frugívoros en la Estación Biológica La Selva. Se analizó 854 muestras de heces y 169 muestras de restos de frutos y semillas en comederos. Durante ocho meses de estudio, se identificó 47 especies de frutos, que fueron consumidos por los murciélagos. Cinco géneros de plantas (Cecropia, Ficus, Piper, Solanum y Vismia) constituyeron el $85 \%$ de los hallazgos en las muestras de heces y los comederos. La amplitud de nicho trófico difirió significativamente entre las seis especies de murciélagos frugívoros más frecuentemente capturados (Artibeus jamaicensis, Carollia sowelli, C. castanea, C. perspicillata, Dermanura sp., Glossophaga commissarisi). Estas especies, con excepción de Dermanura sp., mostraron una dieta dominada por uno o dos táxones de plantas. Esto sugiere un patrón de repartición de recursos a nivel genérico, donde Carollia consumió principalmente plantas del genero Piper, Artibeus consumió Ficus y Cecropia y Glossophaga consumió Vismia. El análisis de conglomerados reveló que existe un mayor solapamiento de nicho trófico entre especies congenéricas que entre especies no congenéricas. Los resultados sugieren que, si el alimento es un factor limitante, algún otro mecanismo -que no es la selección trófica- debe reducir la interferencia o competencia interespecífica por alimentos entre las especies congénericas de murciélagos frugívoros en la EBLS.

Palabras clave: Costa Rica, Estación Biológica La Selva, estructura trófica, hábitos alimentarios, murciélagos frugívoros.

\section{REFERENCES}

Autino, A. \& R. Barquez. 1993. Patrones reproductivos y alimenticios de dos especies simpátricas del género Sturnira (Chiroptera: Phyllostomidae). Mastozool. Neotrop. 1: 73-80.

Anderson, D.J. 1983. Optimal foraging and the traveling salesman. Theoretical Population Biol. 24: 145-159.

Bernard, E. 2001. Vertical stratification of bat communities in primary forests of Central Amazon, Brazil. J. Trop. Ecol. 17: 115-126.

Bonaccorso, F.J. 1979. Foraging and reproductive ecology in a Panamanian bat community. Bull. Florida State Muse. Biol. Sci. 24: 359-408.

Brosset, A., P. Charles-Dominique, A. Cockly, J.F. Cosson \& D. Mason. 1996. Bat communities and deforestation in French Guiana. Can. J. Zool. 74: 1974-1982.

Charles-Dominique, P. 1986. Interrelations between frugivorous vertebrates and pioneer plants: Cecropia, birds and bats in French Guyana, p. 119-135. In A. Estrada \& T. Fleming (eds.). Frugivores and seed dispersal. Dr. W. Junk, The Hague, The Netherlands.

Charles-Dominique, P. 1991. Feeding strategy and activity budget of the frugivorous bat Carollia perspicillata (Chiroptera: Phyllostomidae) in French Guiana. J. Trop. Ecol. 7: 243-256.

Colwell, R.K. \& D.J. Futuyma. 1971. On the measurement of niche breadth and overlap. Ecology. 52: 567-576.

Cosson, J.F., J.M. Pons \& D. Masson. 1999. Effects of forest fragmentation on frugivorous and nectarivorous bats in French Guinea. J. Trop. Ecol. 15: 515-534. 
Dinerstein, E. 1986. Reproductive ecology of fruit bats and the seasonality of fruit production in a Costa Rican cloud forest. Biotropica 18: 307-316.

Fleming, T.H. 1981. Fecundity, fruiting pattern, and seed dispersal in Piper amalago (Piperacea), a bat-dispersed tropical shrub. Oecologia 51: 42-46.

Fleming, T.H. 1982. Foraging strategies of plant-visiting bats, p. 287-321. In T. Kunz (ed.). Ecology of bats. Plenum, New York, USA.

Fleming, T.H. 1986a. The structure of neotropical bat communities: A preliminary analysis. Rev. Chilena. de Hist. Natur. 59: 135-150.

Fleming, T.H. 1986b. Opportunism versus specialization: The evolution of feeding strategies in frugivorous bats, p. 105-118. In A. Estrada \& T. Fleming (eds.). Frugivores and seed dispersal. Dr. W. Junk, The Hague, The Netherlands.

Fleming, T.H. 1988. The short-tailed fruit bat. The University of Chicago, Chicago, Illinois, USA. 365 p.

Fleming, T.H., E.T. Hooper \& D.E. Wilson. 1972. Three Central American bat communities: structure, reproductive cycles and movement patterns. Ecology 53: 555-569.

Fleming, T.H.\& E.R. Heithaus. 1981. Frugivorous bats, seed shadows and the structure of tropical forests. Biotropica 13: 45-53.

Fleming, T.H., C.F. Williams, F.J. Bonaccorso \& L.H. Herbst. 1985. Phenology, seed dispersal, and colonization in Muntingia calabura, a neotropical pioneer tree. Amer. J. Bot. 72: 383-391.

Fleming, T.H., R. Breitwish \& G.H. Whitesides. 1987. Patterns of tropical vertebrate frugivore diversity. Ann. Rev. Ecol. Syst. 18: 91-109.

Frankie, G.W., H.G. Baker \& P.A. Opler. 1974. Comparative phenological studies of trees in tropical wet and dry forests in the lowlands of Costa Rica. J. Ecol. 62: 881-919.

Galindo, J. 1998. Seed dispersion by fruit bats: Its importance in the conservation and regeneration of tropical forests. Acta Zool. Mex. Nueva Ser. 0: 57-74.

Galindo, J., S. Guevara \& V. Sosa. 2000. Bat and bird generated seed rains at isolated trees in pastures in a tropical rainforest. Conserv. Biol. 14: 1693-1703.
Ganesh, T. \& P. Davidar. 2001. Dispersal modes of tree species in the wet forests of southern Western Ghats. Current Sci. 80: 394-399.

Gardner, A. 1977. Feeding habits, p. 293-350. In R.J. Baker, K.C. Jones \& D.C. Carter (eds.). Biology of bats in the New World family Phyllostomatidae Part II. Special Publications of the Museum of Texas Tech University, Lubbock, Texas, México.

Gordhov, D.L., F. Cornejo, C. Ascorra \& M. Jaramillo. 1995. Dietary overlap between frugivorous birds and bats in the Peruvian Amazon. Oikos 74: 235-250.

Greig, N. 1993a. Predispersal seed predation on five species of co-occurring Piper in tropical rainforest. Oecologia 93: 412-420.

Greig, N. 1993b. Regeneration mode in neotropical Piper: habitat and species comparisons. Ecology 74: 2125-2135.

Hammel, B.E. 1986a. The vascular flora of La Selva Biological Station, Costa Rica-Cecropiaceae. Selbyana 9: 192-195.

Hammel, B.E. 1986b. The vascular flora of La Selva Biological Station, Costa Rica-Moraceae. Selbyana 9: 243-259.

Handley, C.O. Jr., A.L. Gardner \& D.E. Wilson. 1991. Food habits, p. 141-146. In C.O. Handley, Jr., D.E. Wilson \& A.L. Gardner (eds.). Demography and natural history of the common fruit bat, Artibeus jamaicensis, on Barro Colorado Island, Panamá. Smithsonian Contrib. Zool. 511: 1-173.

Hartshorn, G.S. \& B.E. Hammel. 1994. Vegetation types and floristic patterns, p. 73-89. In L.A. McDade, K.S. Bawa, H.A. Hespenheide \& G.S. Hartshorn (eds.). La Selva: Ecology and natural history of a neotropical rain forest.. The University of Chicago, Chicago, Illinois, USA.

Heithaus, E.R., T.H. Fleming \& P.A. Opler. 1975. Foraging patterns and resource utilization in seven species of bats in a seasonal tropical forest. Ecology 56: 841854.

Howell, D.J. \& D. Burch. 1974. Food habits of some Costa Rican bats. Rev. Biol. Trop. 21: 284-334.

Hutchinson, G.E. 1959. Homage to Santa Rosalia or why are there so many kinds of animals? Amer. Natur. 145-159. 
Jaksic, F. \& R. Medel. 1987. El acuchillamiento de datos como método de obtención de intervalos de confianza y de prueba de hipótesis para índices ecológicos. Medio Ambiente 8: 95-103.

Janzen, D.H. 1978. Seeding patterns of tropical trees, p. 83-128. In P.B. Tomlinson \& M.H. Zimmerman (eds.) Tropical trees as living systems. Cambridge University, Cambridge, England.

Kalko, E. \& C. Handley. 2001. Neotropical bats in the canopy: Diversity, community structure and implications for conservation. Plant Ecol. 153: 319-333.

Korine, C., E. Kalko \& E. Herre. 2000. Fruit characteristics and factors affecting fruit removal in a Panamanian community of strangler figs. Oecologia 123: 560568

Krebs, C.J. 1989. Ecological methodology. Harper Collins, New York, USA. 655 p.

Kunz, T.H. 1980. Daily energy budgets of free-living bats, p. 369-393. In D.E. Wilson \& L.A. Gardner (eds.) Proceedings of the Fifth International Bat Research Conference. Texas Tech University, Lubbock, USA.

Levey, D.J., T.C. Moermond \& J.S. Denslow. 1994. Frugivory: an overview, p. 282-294. In L.A. McDade, K.S. Bawa, H.E. Hespenheide \& G.S. Hartshorn (eds.). La Selva: Ecology and natural history of a neotropical rain forest. The University of Chicago, Chicago, Illinois, USA

Marinho-Filho, J.S. 1991. The coexistence of two frugivorous bat species and the phenology of their food plants in Brazil. J. Trop. Ecol. 7: 59-67.

Muñoz-Romo, M., M. Sosa \& Y. Casart Quintero. 2005. Digestibilidad del polen de cactáceas columnares en los murciélagos glosofaginos Glossophaga longirostris y Leptonycteris curasoae (Chiroptera: Phyllostomidae). Rev. Biol. Trop. 53(1-2): 277-280.

McDade, L.A. \& G.S. Hartshorn. 1994. La Selva Biological Station, p. 6-14. In L.A. McDade, K.S. Bawa, H.E. Hespenheide \& G.S. Hartshorn (eds.). La Selva: Ecology and natural history of a neotropical rain forest. The University of Chicago, Chicago, Illinois, USA.

McNab, B.K. 1971. The structure of tropical bat faunas. Ecology 52: 352-358

Medellin, R. \& O. Gaona. 1999. Seed dispersal by bats and birds in forest and disturbed habitats of Chiapas, Mexico. Biotropica 31: 478-485.
Millar, J.S. 1978. Energetics of reproduction in Peromyscus leucopus: the cost of lactation. Ecology 59: 10551061.

Morrison, D.W. 1978. Foraging ecology and energetics of the frugivorous bat Artibeus jamaicensis. Ecology 59: 716-723.

Muller, M.F. \& N.R. Reis. 1993. Partition of food resources among four species of frugivorous bats (Chiroptera: Phyllostomidae). Rev. Brasiliera Zool. 9: 345-355.

Newstrom, L.E., G.W. Frankie, H.G. Baker \& R.K. Colwell. 1994. Diversity of long-term flowering patterns, p. 142-160. In L.A. McDade, K.S. Bawa, H.E. Hespenheide \& G.S. Hartshorn (eds.). La Selva: Ecology and natural history of a neotropical rain forest. The University of Chicago, Chicago, Illinois, USA.

Ochoa, G.J. 2000. Effects of selective logging on the diversity of small mammals in the lowland forests of the Venezuelan Guyana region. Biotropica 32: 146-164.

Opler, P.A., G.W. Frankie \& H.G. Baker. 1980. Comparative phenological studies of treelet and shrub species in tropical wet and dry forests in the lowlands of Costa Rica. J. Ecol. 68: 167-188.

Pacheco, J., G. Ceballos, G.C. Daily, P.R. Ehrlich, G. Suzán, B. Rodríguez-Herrera \& E. Marcé. 2006. Diversidad, historia natural y conservación de los mamíferos de San Vito de Coto Brus, Costa Rica. Rev. Biol. Trop. 54: 219-240.

Parrotta, J.A., O.H. Knowles \& J. Wunderle. 1997. Development of floristic diversity in 10-year-old restoration forests on a bauxite mined site in Amazonia. Forest. Ecol. Manage. 99: 21-42.

Pianka, E.R. 1973. The structure of lizard communities. Annu. Rev. Ecol. Syst. 4: 53-74

Pyke, G.H., H.R. Pulliam \& E.L. Charnov. 1977. Optimal foraging: a selective review of theory and tests. Quart. Rev. Biol. 52: 137-154.

Racey, P.A. 1988. Ecology of bat reproduction, p. 57-104. In T. Kunz (ed.). Ecology of bats. Plenum, New York, USA.

Randolph, P.A., J.C. Randolph, K. Mattingly \& M.M. Foster. 1977. Energy cost of reproduction in the cotton rat, Sigmodon hispidus. Ecology 58: 31-45.

Sanford, R.L., P. Paaby, J.C. Luvall \& E. Phillips. 1994. Climate, geomorphology, and aquatic systems, p. 19- 
33. In L.A. McDade, K.S. Bawa, H.E. Hespenheide \& G.S. Hartshorn (eds.). La Selva: Ecology and natural history of a neotropical rain forest.. The University of Chicago, Chicago, Illinois, USA.

Schulze, M.D., N.E. Seavy \& D.F. Whitacre. 2000. A comparison of the phyllostomid bat assemblages in undisturbed neotropical forest and in forest fragments of a slash-and-burn framing mosaic in Peten, Guatemala. Biotropica 32: 174-184.

Shanahan, M., R.D. Harrison, R. Amuna, W. Boen \& I.W. Thornton. 2001. Colonization of an island volcano, Long Island, Papua New Guinea, an emergent island, in its caldera lake. V. Colonization by figs (Ficus spp.), their dispersers and pollinators. J. Biogeogr. 28: 1365-1377.

Snow, D.W. 1965. A possible selective factor in the evolution of fruiting season in tropical forests. Oikos 274-281.

Sokal, R.R. \& F.J. Rohlf. 1981. Biometry. Freeman, New York, USA. 859 p.

Sosa, M. \& P. Soriano. 1993. Solapamiento de dieta entre Leptonycteris curasoae y Glossophaga longirostris (Mammalia: Chiroptera). Rev. Biol. Trop. 41: 529-532.

Stashko, R.E. \& T.H. Kunz. 1987. The economic importance of bat-visited plants in Latin America. Final report submitted to World Wildlife Fund-US. Washington, D.C., USA.

Statistical Graphics Corporation. 1994. Statgraphic Plus for Windows. Statistical Graphics. Rockville, Maryland, USA. 450 p.

Tamsitt, J.R. 1967. Niche and species diversity in neotropical bats. Nature 213: 784-786.

Thomas, D.W. 1988. Analysis of diets of plant-visiting bats, p. 211-221. In T.H. Kunz (ed.). Ecological and behavioral methods for the study of bats. Smithsonian Institution. Washington, D.C., U.S.A.

Timm, R.M. 1987. Tent construction by bats of the genera Artibeus and Uroderma, p. 187-212. In B.D. Petterson \& R. Timm (eds.). Studies in neotropical mammalogy: Essays in honor of Philip Hershkovitz. Fieldiana: Zoology, Field Museum, Chicago, Illinois, USA.

Timm, R.M. 1994. The mammal fauna, p. 229-237. In L.A. McDade, S.K. Bawa, H.A. Hespenheide \& G.S. Hartshorn (Eds.). La Selva: Ecology and natural history of a neotropical rain forest. The University of Chicago, Chicago, Illinois, USA.

Wendeln, M. 2000. Nutritional values of 14 fig species and bat feeding preferences in Panama. Biotropica 32: 489-501. 
